\title{
Cloning and Expression of a Bacillus subtilis Endo-1,3-1,4- $\beta$-D-Glucanase Gene in Escherichia coli K12
}

\author{
By EDWARD HINCHLIFFE \\ Research Department, Bass PLC, 137 High Street, Burton on Trent DE14 1JZ, UK
}

(Received 22 September 1983)

EcoRI fragments of DNA from Bacillus subtilis NCIB 8565, a high producer of an endo-1,3-1,4$\beta$-D-glucanase, were 'shot-gun' cloned in the plasmid vector pBR325. A $3.5 \mathrm{~kb}$ insert, carrying single restriction sites for $A v a \mathrm{I}, B g I I \mathrm{I}, C l a \mathrm{I}, P v u \mathrm{I}$ and $P v u I I$, was shown to direct the synthesis of $\beta$-glucanase in Escherichia coli K12. Enzyme activity was demonstrated in extracellular fractions of $E$. coli harbouring the $\beta$-glucanase gene; however, the largest proportion ( $>50 \%$ ) of total enzyme activity was periplasmic in location. $\beta$-Glucanase activity and cellular location were independent of the orientation of the $3.5 \mathrm{~kb}$ fragment in pBR325.

\section{INTRODUCTION}

The Gram-positive bacterium Bacillus subtilis produces an extracellular endolytic enzyme (1,3-1,4- $\beta$-D-glucan 4-glucanohydrolase; EC 3.2.1.73) capable of hydrolysing alternating sequences of $\beta 1,3$ - and $\beta 1,4-$ linked $\beta$-D-glucans (Moscatelli et al., 1961; Rickes et al., 1962). The unique action of this enzyme precludes its ability to hydrolyse repeating sequences of $\beta 1,3-$ or $\beta 1,4$-linked glucans as in laminarin and carboxymethylcellulose, respectively. In this respect the B. subtilis enzyme behaves like that isolated from malted barley (Barras et al., 1969; Manners \& Wilson, 1976). There is considerable interest in the brewing industry in enzymes produced by bacteria and fungi, and their ability to complement the enzymes present in malt (Godfrey, $1983 a$ ). Strains of $B$. subtilis have already been developed for the production of $\beta$-glucanase for industrial purposes (Godfrey, 1983b). However, commercial enzyme preparations are impure and often have variable and unpredictable properties (C. W. Bamforth, personal communication). Consequently the cloning, expression and concomitant amplification of a $\beta$-glucanase gene will assist in the further characterization and purification of the enzyme for industrial use. In addition, the availability of a cloned gene affords the possibility of modifying brewing yeasts to degrade $\beta$-glucan during beer fermentations, thus alleviating problems associated with high levels of $\beta$-glucan in beer, such as filtration and the formation of gels and hazes (Bamforth, 1982).

Here I describe the screening of several $B$. subtilis strains for their ability to hydrolyse barley $\beta$ glucan, and report the cloning and expression of a $\beta$-glucanase gene from strain NCIB 8565 in Escherichia coli. A $B$. subtilis gene coding for a $\beta$-glucanase has recently been cloned and expressed in $E$. coli using bacteriophage $\lambda$ and plasmid vectors; the active gene has been located within a $1.6 \mathrm{~kb} E c o$ RI-PvuI DNA fragment and directs the synthesis of an extracellular enzyme in E. coli (Cantwell \& McConnell, 1983).

\section{METHODS}

Bacterial strains and plasmids. The strains of $B$. subtilis used were: NCIB 3610, 8057, 8054, 8565, 8646, 10144 (National Collection of Industrial Bacteria); BGSC 2A1, 3A1, 3A11 (Bacillus Genetic Stock Center, Ohio State University, USA); $168 \operatorname{trp} C 2$ (supplied by J. Errington, Dept of Biochemistry, University of Oxford, UK). The

Abbreviations: Ap, ampicillin; $\mathrm{Cm}$, chloramphenicol; Tc, tetracycline. 
host strain of $E$. coli K12 was HB101 (hsdS leu pro lac gal strA thi recA) (Boyer \& Roulland-Dussoix, 1969). The $E$. coli plasmid vector was pBR325 (Bolivar, 1978).

Media and growth conditions. LB medium (Bertani, 1951) was used for the growth of liquid cultures, and was aerated by shaking at $37^{\circ} \mathrm{C}$. LB medium was solidified with $1.5 \%(\mathrm{w} / \mathrm{v})$ agar to make LA plates. When appropriate, LA medium was supplemented with $0.05 \%$ (w/v) barley $\beta$-glucan (Biocon, Eardiston, UK).

Antibiotics. These were obtained from Sigma and were added to media as freshly prepared solutions at the following final concentrations $\left(\mu \mathrm{g} \mathrm{ml}^{-1}\right)$; ampicillin (Ap), 25; tetracycline (Tc), 15; chloramphenicol $(\mathrm{Cm}), 30$.

Detection and assay for $\beta$-glucanase activity. Bacterial colonies were screened for $\beta$-glucanase activity by a modification of the Congo Red screening method of Teather \& Wood (1982). Bacterial colonies growing on LA plus $\beta$-glucan were replica-plated to selective media and the master plate was washed and stained with Congo Red $(0.04 \%, w / v)$. The colonies producing $\beta$-glucanase were surrounded by a zone of clearing against a red-stained agar. A similar method has recently been described by Cantwell \& McConnell (1983).

The $\beta$-glucanase activity associated with culture supernatants was assayed by the radial diffusion assay of Martin \& Bamforth (1983). $\beta$-Glucan substrate was either barley $\beta$-glucan (Biocon) or Lichenan (from Usnea barbata; Sigma). $\beta$-Glucanase activity was determined by measuring the clearing diameter ( $\mathrm{mm}$ ) and converting to arbitrary units as defined by Martin and Bamforth (1983).

Preparations were also assayed for the ability to liberate reducing sugars from $\beta$-glucan (barley $\beta$-glucan; laminarin, Sigma; carboxymethylcellulose, BDH). Enzyme preparation $(0.05-0.1 \mathrm{ml})$ was added to $0.5 \mathrm{ml} \beta$ glucan $\left(2 \mathrm{mg} \mathrm{ml}^{-1}\right)$; the reaction was made to $1 \mathrm{ml}$ with $\mathrm{H}_{2} \mathrm{O}$ and incubated at $50^{\circ} \mathrm{C}$ for $10 \mathrm{~min}$. Reactions were stopped with the addition of $1 \mathrm{ml}$ dinitrosalicylic acid solution $(0.25 \mathrm{~g} \mathrm{3,5-dinitrosalicylic} \mathrm{acid,} 5 \mathrm{ml} 2 \mathrm{M}-\mathrm{NaOH}$, $12 \mathrm{ml} \mathrm{H} 2 \mathrm{O} ; 7.5 \mathrm{~g}$ potassium sodium tartrate diluted to $25 \mathrm{ml}$ ) and boiling for $10 \mathrm{~min}$. After the addition of $5 \mathrm{ml}$ $\mathrm{H}_{2} \mathrm{O}$ the amount of reducing sugar was estimated by reading the absorption at $540 \mathrm{~nm}$. One unit of activity was defined as the amount of enzyme capable of liberating $1 \mu \mathrm{mol}$ reducing sugar $\min ^{-1}$ (using maltose as reference) under the conditions described above.

Extracellular, periplasmic and cellular enzyme fractions. These were prepared and defined as described by Cornelis et al. (1982) with the exception that cells were washed in $0 \cdot 2 \mathrm{M}-\mathrm{Na}_{2} \mathrm{HPO}_{4} \cdot 2 \mathrm{H}_{2} \mathrm{O}, 0 \cdot 1 \mathrm{M}$-citric acid, $\mathrm{pH} 5 \cdot 6$.

Isolation of DNA. Plasmid DNA was isolated by caesium chloride/ethidium bromide equilibrium centrifugation of cleared cell lysates using the method of Clewell \& Helinski (1969), with the modifications of Zahn et al. (1977). Chromosomal DNA was isolated from exponentially growing cells following Triton lysis (Katz et al., 1973), with the modifications of Kaiser \& Murray (1979). For some experiments a rapid small-scale plasmid extraction procedure was used (Birnboim \& Doly, 1980).

Restriction, ligation and electrophoresis of DNA. Restriction endonucleases were purchased from Bethesda Research Laboratories and Boehringer and were used according to the manufacturers' recommendations. Recombinant plasmids containing $B$. subtilis genomic DNA were obtained by the in vitro ligation of endonuclease EcoRI-generated fragments in the vector pBR325. DNA $\left(25 \mu \mathrm{g} \mathrm{ml}^{-1}\right)$ was ligated with T4 DNA ligase (New England Biolabs, Bishop's Stortford, UK; 5-10 units $\mathrm{ml}^{-1}$ ) at $15^{\circ} \mathrm{C}$, in $0.1 \mathrm{M}-\mathrm{Tris} / \mathrm{HCl}(\mathrm{pH} 7 \cdot 2$ ), 0.01 $\mathrm{M}-\mathrm{EDTA}$, $0.1 \mathrm{M}-\mathrm{MgCl}_{2}, 0.1 \mathrm{M}$-dithiothreitol and $0.01 \mathrm{M}$-ATP. DNA fragments produced by endonuclease digestion were analysed by agarose gel electrophoresis (Helling et al., 1974).

Transformation. This was done as described by Wilson \& Murray (1979).

\section{RESULTS}

\section{Identification of a $\beta$-glucanase gene donor}

Preliminary screening of ten $B$. subtilis strains by the radial diffusion method indicated that there was considerable variation in enzyme activity, with clearing zones varying in diameter from 9 to $20 \mathrm{~mm}$ on barley $\beta$-glucan (10 and $>548$ arbitrary units $\mathrm{ml}^{-1}$, respectively). Four strains, listed in Table 1 , were identified as having significantly higher $\beta$-glucanase activity than the remaining six. Strain NCIB 8565 produced the highest levels of $\beta$-glucanase activity, whether determined on barley $\beta$-glucan or lichenan. This strain was therefore adopted as the most suitable donor of a $\beta$-glucanase gene. When culture supernatants of $E$. coli HB101 were assayed for $\beta$-glucanase activity, there was no detectable zone of clearing, confirming the supposition that $E$. coli lacks a functional $\beta$-glucanase enzyme.

\section{Construction and isolation of recombinant plasmids carrying the $\beta$-glucanase gene of NCIB 8565}

B. subtilis DNA was cut with EcoRI and ligated to $E c o$ RI-digested pBR325 DNA as described above. The ligated molecules were then transformed into HB101 and the resulting transformants 
Table 1. Radial diffusion assay for $\beta$-glucanase activity in B. subtilis

\begin{tabular}{|c|c|c|c|}
\hline \multirow[b]{2}{*}{ Strain } & \multicolumn{2}{|c|}{ Barley $\beta$-glucan } & \multirow{2}{*}{$\begin{array}{c}\text { Lichenan } \\
\text { Diameter }(\mathrm{mm})^{*}\end{array}$} \\
\hline & Diameter $(\mathrm{mm})^{*}$ & Activity & \\
\hline BGSC 3A11 & 14 & 74 & $9 \cdot 5$ \\
\hline NCIB 3610 & 18 & 367 & $12 \cdot 0$ \\
\hline NCIB 8565 & 20 & $>548$ & $13 \cdot 5$ \\
\hline NCIB 8646 & 18 & 367 & $13 \cdot 0$ \\
\hline
\end{tabular}

* $0.1 \mathrm{ml}$ of $16 \mathrm{~h} \mathrm{LB}$ cultures assayed as described in Methods.

$\dagger$ Arbitrary units of $\beta$-glucanase activity $\mathrm{ml}^{-1}$ (according to Martin \& Bamforth, 1983).

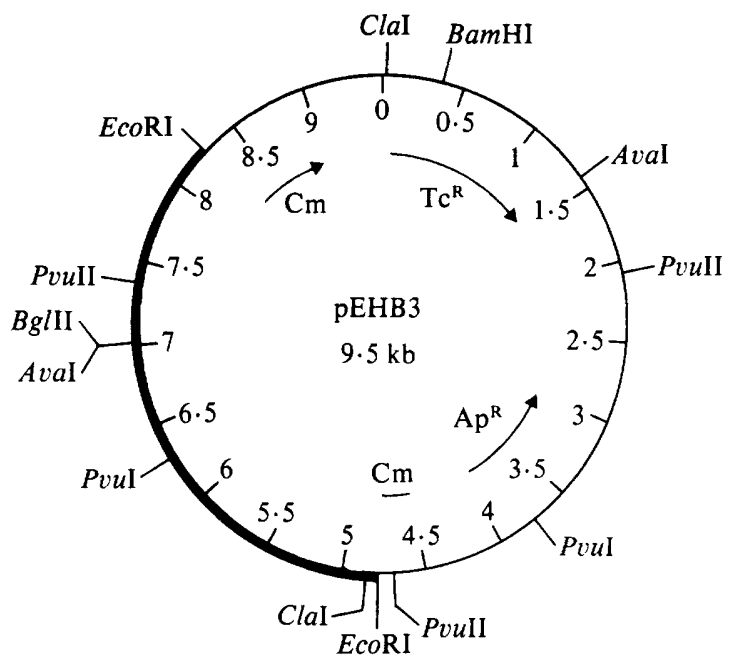

Fig. 1. Physical map of plasmid pEHB3, obtained from restriction endonuclease digestion and agarose gel electrophoresis of plasmid DNA. - B. subtilis (NCIB 8565) DNA; —, pBR325 DNA. The numbers indicate the size of the DNA in $\mathrm{kb}$. The arrows represent the position and direction of transcription of the genes which mediate resistance to the antibiotics ampicillin ( $\left.A p^{R}\right)$, tetracycline $\left(\mathrm{Tc}^{\mathrm{R}}\right)$ and chloramphenicol $\left(\mathrm{Cm}^{\mathrm{R}}\right)$ (Soberon et al., 1980). pEHB3 is phenotypically chloramphenicolsensitive due to the insertional inactivation of the chloramphenicol acetyltransferase gene. No restriction sites were found within the $3.5 \mathrm{~kb}$ insert DNA for the restriction endonucleases BamHI, HindIII, PstI, Sall and SmaI.

plated on LA supplemented with barley $\beta$-glucan and ampicillin. Of approximately 20000 transformants screened for $\beta$-glucanase activity, seven showed areas of $\beta$-glucan degradation. Five of these transformants were selected and purified and the plasmid DNA was analysed by restriction with EcoRI. All five transformants harboured plasmids, designated pEHB3-7 respectively. Each plasmid possessed an EcoRI fragment of $3.5 \mathrm{~kb}$. When strains of $\mathrm{HB} 101$ harbouring plasmids pEHB3-7 were replicated to media containing chloramphenicol and tetracycline, all showed a chloramphenicol sensitive phenotype, indicative of the insertional inactivation of the chloramphenicol acetyltransferase gene. Plasmid DNA isolated from each of the five recombinants and re-transformed to HB101 conferred the ability to degrade $\beta$-glucan upon all the recipient clones.

\section{Restriction mapping of pEHB3}

The recombinant plasmid pEHB3 was singled out for a more detailed analysis of its recombinant DNA. Restriction endonuclease digestion with a variety of different enzymes resulted in a preliminary restriction map (Fig. 1). This shows that the $3.5 \mathrm{~kb} E c o$ RI fragment 
Table 2. Levels of $\beta$-glucanase activity and cellular location in $H B 101(p E H B 3)$ and $H B 101(p E H B 5)$

Cellular fractions were assayed for the ability to liberate reducing sugars from barley $\beta$-glucan. $\beta$-Glucanase activity is expressed as units per $\mathrm{ml}$ of culture grown in $50 \mathrm{ml} \mathrm{LB} \mathrm{Ap}$ medium for $16 \mathrm{~h}$ at $37^{\circ} \mathrm{C}$. The data presented indicate the range of values obtained for two independent experiments labelled A and B. Numbers in parentheses represent the mean $\beta$-glucanase activity in each fraction expressed as a percentage of the total activity.

Cellular fraction

Extracellular
Periplasmic
Cellular
Total

Extracellular
Periplasmic
Cellular

Total

\begin{tabular}{ccl}
\multicolumn{4}{c}{ HB101(pEHB3) } \\
A & \multicolumn{1}{c}{ B } & \\
0.23 & 0.5 & $(26)$ \\
0.62 & 0.99 & $(57 \cdot 3)$ \\
0.20 & 0.27 & $(16.7)$ \\
1.05 & 1.76 & $(100)$
\end{tabular}

\begin{tabular}{ccc}
\multicolumn{4}{c}{ HB101(pEHB5) } \\
A & B & \\
0.19 & 0.23 & $(23 \cdot 4)$ \\
0.54 & 0.45 & $(55 \cdot 3)$ \\
0.13 & 0.25 & $(21 \cdot 3)$ \\
0.86 & 0.93 & $(100)$
\end{tabular}

possesses a single asymmetric $P v u I I$ site, which was used subsequently to map the orientation of the EcoRI inserts in plasmids pEHB5-7.

\section{Orientation of the $3.5 \mathrm{~kb}$ EcoRI fragment in plasmids $\mathrm{pEHB3-7}$}

Plasmids pEHB5-7 were digested with the restriction endonuclease $P v u I I$ to determine the orientation of insertion of the EcoRI fragment in the EcoRI site of pBR325. PvuII digestion of pEHB6 and pEHB7 generated fragments of approximately $4.2,2.6$ and $2.7 \mathrm{~kb}$, indicating that each carried the EcoRI fragment in the same orientation as pEHB3 (Fig. 1), whereas pEHB5 gave fragments of approximately $6.0,2.6$ and $1.0 \mathrm{~kb}$ upon PvulI digestion, indicating that the EcoRI fragment was in the opposite orientation to that described for pEHB3 (Fig. 1).

\section{Substrate specificity of the $\beta$-glucanase enzyme produced by E. coli HB101(pEHB3)}

The supernatant from an overnight $(16 \mathrm{~h}$ ) culture of HB101(pEHB3) on LB Ap medium was assayed for the ability to hydrolyse barley $\beta$-glucan, laminarin (1,3- $\beta$-D-glucan) and carboxymethylcellulose (1,4- $\beta$-D-glucan). The production of reducing sugars was determined in order to assess the substrate specificity of the enzyme. There was no apparent hydrolysis of either laminarin or carboxymethylcellulose under the conditions described in Methods. However, barley $\beta$-glucan was hydrolysed (a value of $0.21 \beta$-glucanase units $\mathrm{ml}^{-1}$ ), indicating that the enzyme was specific for mixed-linkage $1,3-1,4-\beta$-D-glucan.

\section{Expression and cellular location of $\beta$-glucanase activity in E. coli $\mathrm{HB} 101$}

$\beta$-Glucanase activity was estimated in HB101(pEHB3) and HB101(pEHB5), to determine whether the orientation of insertion of the $3.5 \mathrm{~kb} E c o$ RI fragment in pBR325 affected the level of enzyme expression and/or cellular location. Extracellular, periplasmic and cellular fractions were assayed for the ability to liberate reducing sugars from barley $\beta$-glucan. From Table 2 it appears that $\mathrm{HB} 101$ (pEHB3) produces approximately 1.6 times more $\beta$-glucanase than HB101(pEHB5), under the same conditions. However, there is little difference in the relative location of the enzyme for each strain, the highest activity being associated with the periplasmic fraction (Table 2).

The production of $\beta$-glucanase was followed more closely in a culture of HB101(pEHB3), in order to determine the location of the enzyme during cell growth. Samples were taken from the culture at intervals and treated to separate extracellular, periplasmic and cellular activities. There was a rapid increase in total activity as the culture commenced exponential growth (Fig. 2). This increase was followed closely by an initial increase in cellular activity, indicative of enzyme synthesis. As the culture entered late exponential growth the periplasmic and extracellular activity increased at the expense of the cellular, suggesting movement of the newly synthesized enzyme into the periplasm and subsequently the culture supernatant (Fig. 2). 


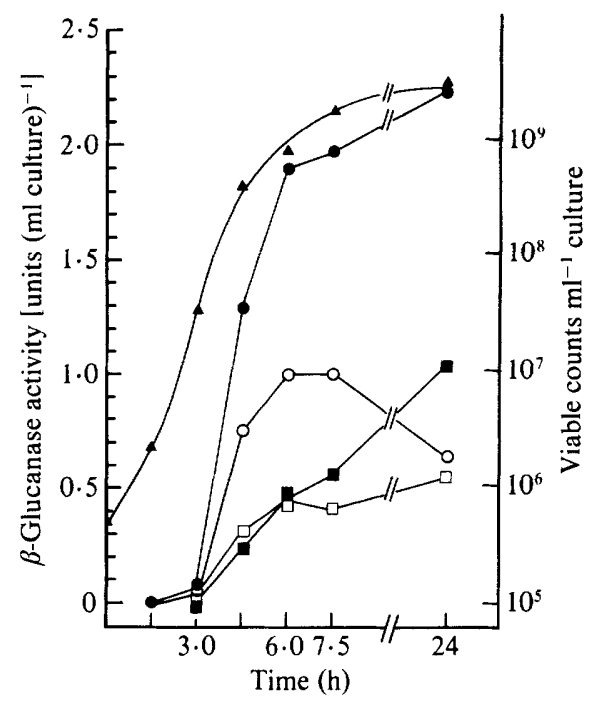

Fig. 2. Kinetics of $\beta$-glucanase production in a culture of HB101(pEHB3); periplasmic activity; $\square$, extracellular activity; $\bigcirc$, cellular activity. Viable counts $(\boldsymbol{\Delta})$ were determined by plating serial dilutions on LA Ap medium.

\section{DISCUSSION}

The evidence presented in this paper is consistent with the cloning of a $B$. subtilis $\beta$-glucanase gene and its expression in $E$. coli. The enzyme present in cell-free culture supernatants of strain HB101(pEHB3) was specific for mixed linkage 1,3-1,4- $\beta$-D-glucan, and in this respect was identical to the endo-1,3-1,4- $\beta$-D-glucanase (EC 3 2 2 1 .73) isolated from $B$. subtilis (Moscatelli et al., 1961).

The active $\beta$-glucanase gene was located on a $3.5 \mathrm{~kb} E c o R I$ fragment common to all the recombinant plasmids isolated in HB101. Estimates of $\beta$-glucanase activity in HB101(pEHB3) and $\mathrm{HB101}$ (pEHB5) indicated that the former produced more $\beta$-glucanase, suggesting that the orientation of the $E c o$ RI fragment in pBR 325 may be important. The fact that each plasmid was able to direct the synthesis of the enzyme would imply that expression was not brought about by gene fusion with adjacent vector sequences, since a functional hybrid protein would be unlikely to be generated in both orientations. However, the difference in the level of expression between pEHB3 and pEHB5 may be due to the influence of vector sequences acting upon the $\beta$-glucanase gene. Whatever the explanation, it seems likely that the $\beta$-glucanase gene is directing its own transcription and translation in $E$. coli. A $4 \mathrm{~kb} E c o$ RI DNA fragment recently isolated from $B$. subtilis NCIB 2117 has also been shown to express $\beta$-glucanase activity in $E$. coli, independently of its orientation in the plasmid vector pBR325 (Cantwell \& McConnell, 1983). The $\beta$-glucanase gene described by Cantwell \& McConnell (1983) has been located on a $1.6 \mathrm{~kb}$ EcoRI-PvuI fragment within the $4 \mathrm{~kb} E c o \mathrm{RI}$ insert. However, comparison of the restriction site data between the two EcoRI fragments shows differences in the relative location of the single $A v a \mathrm{I}$ site. In addition, the $3.5 \mathrm{~kb} E c o \mathrm{RI}$ insert in pEHB3 has single restriction sites for the enzymes $C l a$ I and PvuII which are absent in the $4 \mathrm{~kb} E c o$ RI fragment (Cantwell \& McConnell, 1983). In contrast, the $4 \mathrm{~kb} E c o$ RI fragment has a single site for $S a l$ which is not present in pEHB3 (Fig. 1). This would indicate a degree of intraspecific variation in $B$. subtilis. It will be interesting to make a more detailed comparison of the two genes by DNA sequence analysis.

Amylase genes recently isolated from Bacillus coagulans (Cornelis et al., 1982) and B. subtilis (Yang et al., 1983) express functional gene products in $E$. coli. In the former case the expressed protein was found to reside mainly in the periplasm (Cornelis et al., 1982). Here I describe a similar phenomenon for the $\beta$-glucanase enzyme, which appears to be predominantly periplasmic in location, although appreciable activity can be found in extracellular fractions. The pattern of enzyme synthesis displayed in cultures of HB101(pEHB3) is much as one would 
expect for an extracytoplasmic enzyme, whose passage from the periplasmic space is impeded by the selective permeability of the outer membrane. The absence of an outer membrane in Gram-positive bacteria precludes the possibility of a direct comparison of cellular location in $B$. subtilis. However, the observation that the enzyme is able to translocate across the inner membrane into the periplasm suggests that the protein possesses all the necessary information for its own export in E. coli. According to the signal hypothesis of Blobel \& Dobberstein (1975), the relevant information for export is contained within a 'signal sequence' in the $\mathrm{N}$-terminus of the protein. Such signal sequences have been found in most secretory proteins (Kreil, 1981). Whether a similar situation exists for the $B$. subtilis $\beta$-glucanase enzyme remains to be determined.

I would like to thank the directors of Bass PLC for permission to publish this paper. I would also like to thank Mrs W. G. Box for technical assistance, and C. W. Bamforth, S. W. Molzahn and E. F. Walton for many helpful discussions and comments on the manuscript.

\section{REFERENCES}

BAMFORTH, C. W. (1982). Barley $\beta$-glucans. Their role in malting and brewing. Brewers Digest June, 22-35.

Barras, D. R., Moore, A. E. \& Stone, B. A. (1969). Enzyme substrate relationships among $\beta$-glucan hydrolases. In Cellulases and Their Applications (156th Meeting of the American Chemical Society, September 11-12 1968), pp. 105-138. Atlantic City: American Chemical Society.

BertanI, G. (1951). Studies on lysogenesis. I. The mode of phage liberation by lysogenic Escherichia coli. Journal of Bacteriology 62, 293-300.

Birnboim, H. C. \& Doly, J. (1980). A rapid alkaline extraction procedure for screening recombinant plasmid DNA. Nucleic Acids Research 7, 1513-1523.

BLOBEL, G. \& DobBersteIN, B. (1975). Transfer of proteins across membranes. I. Presence of proteolytically processed and unprocessed nascent immunoglobulin light chains on membrane-bound ribosomes of murine myeloma. Journal of Cell Biology 67, 835851.

Bolivar, F. (1978). Construction and characterization of new cloning vehicles. III. Derivatives of plasmid pBR322 carrying unique EcoRI sites for selection of EcoRI generated recombinant DNA molecules. Gene 4, 121-136.

BOYeR, H. W. \& Roulland-Dussorx, D. (1969). A complementation analysis of the restriction and modification of DNA in Escherichia coli. Journal of Molecular Biology 41, 459-472.

Cantwell, B. A. \& McConnell, D. J. (1983). Molecular cloning and expression of a Bacillus subtilis $\beta$-glucanase gene in Escherichia coli. Gene 23, 211-219.

Clewell, D. B. \& Helinski, D. R. (1969). Supercoiled circular DNA-protein complex in E. coli. Purification and induced conversion to an open circular DNA form. Proceedings of the National Academy of Sciences of the United States of America 62, 11591166.

Cornelis, P., Digneffe, C. \& Willemot, K. (1982). Cloning and expression of a Bacillus coagulans amylase gene in Escherichia coli. Molecular and General Genetics 186, 507-511.

GoDFREY, T. (1983a). Brewing. In Industrial Enzymo- $\log y$, pp. 221-259. Edited by T. Godfrey \& J. Reichelt. London: Macmillan.

GodfreY, T. (1983b). Comparison of key characteristics of industrial enzymes by type and source. In Industrial Enzymology, pp. 466-502. Edited by T. Godfrey \& J. Reichelt. London: Macmillan.

Helling, R. B., Goodman, H. M. \& Boyer, H. W. (1974). Analysis of endonuclease R. EcoRI fragments of DNA from lambdoid bacteriophages and other viruses by agarose gel electrophoresis. Journal of Virology 14, 1235-1244.

KATZ, L., KingSBURY, D. T. \& HelinSKI, D. R. (1973). Stimulation by cyclic adenosine monophosphate of plasmid deoxyribonucleic acid replication and catabolite repression of the plasmid deoxyribonucleic acid-protein relaxation complex. Journal of Bacteriology 114, 577-591.

KAISER, K. \& MURRAY, N. E. (1979). Physical characterization of the ' $R a c$ prophage' in E. coli K12. Molecular and General Genetics 175, 159-174.

KREIL, G. (1981). Transfer of proteins across membranes. Annual Review of Biochemistry 50, 317-348.

Manners, D. J. \& Wilson, G. (1976). Purification of malted barley endo- $\beta$-D-glucanase by ion exchange chromatography: some properties of an endo-barley$\beta$-D-glucanase. Carbohydrate Research 48, 255-264.

Martin, H. L. \& Bamforth, C. W. (1983). Application of a radial diffusion assay for the measurement of $\beta$-glucanase in malt. Journal of the Institute of Brewing 89, 34-37.

Moscatelli, E. A., Ham, E. A. \& Rickes, E. L. (1961). Enzymatic properties of a $\beta$-glucanase from Bacillus subtilis. Journal of Biological Chemistry 236, 28582862.

Rickes, E. L., Ham, E. A., Moscatelli, E. A. \& OTT, W. H. (1962). The isolation and biological properties of a $\beta$-glucanase from $B$. subtilis. Archives of Biochemistry and Biophysics 69, 371-375.

Soberon, X., Covarrubias, L. \& Bolivar, F. (1980). Construction and characterization of new cloning vehicles. IV. Deletion derivatives of pBR322 and pBR325. Gene 9, 287-305.

Teather, R. M. \& Wood, P. J. (1982). Use of Congo red-polysaccharide interactions in enumeration and 
characterization of cellulytic bacteria from the bovine rumen. Applied and Environmental Microbiology 43, 777-780.

Wilson, G. G. \& Murray, N. E. (1979). Molecular cloning of the DNA ligase gene from bacteriophage T4. Molecular and General Genetics 156, 203-214.
YANG, M., GalizzI, A. \& HenNer, D. (1983). Nucleotide sequence of amylase gene from Bacillus subtilis. Nucleic Acids Research 11, 237-249.

ZAHN, G., TIPPE-SchindleR, R. \& Messer, W. (1977). Transdominance of dnaA mutants in Escherichia coli. Molecular and General Genetics 153, 45-49. 